\title{
Morphological Characterization of Kurnool Strains of Chickpea Collar Rot Casual Agent Sclerotium rolfsii Sacc.
}

\author{
M. Saileela ${ }^{1}$, M. Lal Ahamed ${ }^{1}$, J. V. Ramana ${ }^{1 *}$ and S. Khayum Ahamed ${ }^{2}$ \\ ${ }^{I}$ Department of Molecular Biology and Biotechnology, APGC, Lam, Guntur, India \\ ${ }^{2}$ Department of Plant Pathology, AICRP on Chickpea, RARS, Nandyal, India \\ *Corresponding author
}

\begin{tabular}{l} 
K e y w o r d s \\
$\begin{array}{l}\text { Sclerotium rolfsii, } \\
\text { Morphological } \\
\text { characterization, } \\
\text { Mycelia and } \\
\text { Sclerotial } \\
\text { parameters }\end{array}$ \\
\hline Article Info \\
$\begin{array}{l}\text { Accepted: } \\
\text { 04 August } 2020 \\
\text { Available Online: } \\
\text { 10 September } 2020\end{array}$ \\
\hline
\end{tabular}

Keywords

Sclerotium rolfsii

Morphological

characterization

Mycelia and

Sclerotia

Article Info

Accepted:

Available Online:

10 September 2020

\section{A B S T R A C T}

Sclerotium rolfsii causing collar rot is a major disease affecting crop stand and yield in chickpea. A comprehensive study was performed to report the variability in Sclerotium rolfsii isolates present in a major chick pea growing area, Kurnool District of Andhra Pradesh. A roving survey was conducted to collect 50 samples and was used for isolation of disease causing pathogen. 18 isolates of Sclerotium rolfsii were isolated to study the variability in morphological and cultural characteristics in the present study. The variation noted for mycelial traits and sclerotial characters were very huge. The trait, total colony diameter, values after 72 hours of incubation ranged from $42 \mathrm{~mm}$ to $72 \mathrm{~mm}$ and was exploited to classify the isolates as slow, medium and fast. The colour of the mycelia colony was pure white to dull white while, colony morphology or topography varied from compact to fluffy in some isolates. Further, the trait, sclerotia initiation, varied significantly from 5 to 10 days indicating the aggressiveness of the isolates in causing the disease. Sclerotia colour was light brown to dark brown and black in KCSR 16 and the shape was round, spherical to oval and irregular in few. The test weight (100 sclerotia) was ranged from 40 to $320 \mathrm{mg}$ and the number varied from 25 to 124 indicating presence of sufficient variability among the isolates for characterization. This characterization of S.rolfsii isolates is necessary to devise effective management strategies to control the disease.

\section{Introduction}

Chickpea (Cicer arietinum L.; $2 \mathrm{n}=14$ ) is a major legume of the world. It is an annual crop and had the capability to fix atmospheric nitrogen in the soil. It is a crop of subsistence farming and completes its life cycle within 90 days and provides economic benefits to the farming community. The desi and kabuli types are highly cultivated in India and the yields of these genotypes are highly fluctuating over the years. The reason for yield fluctuations is mainly due to the various biotic and abiotic stresses. Among the biotic stresses, diseases caused by the pathogens affecting root like wilts and root rots are of special significance as they affect the crop stand in the initial stages of crop growth and reduce the yield. Sclerotium rolfsii is one of the major pathogen of soil borne nature and 
causes collar rot in chickpea. This disease is getting lot of importance at present because of its effect on the seedlings mortality in early stages of plant growth i.e., 54.7-95\% in conducive environment (Aycock et al., 1966 and Kotasthane et al., 1976) and yield loss of up to $10-30 \%$ in India (Maurya et al., 2008). In Andhra Pradesh, the incidence of this disease is reported to be increasing year after year i.e., $6.31 \%$ - $12.21 \%$ (Nagamani et al., 2015).

The management strategies for this disease are with limited success as the pathogen has wide host range of 500 species, presence of variations among the isolates, growth habit in favourable environments, saprophytic nature and production of dormant structures like sclerotia during unfavourable environmental conditions. The existence of geographical variability among $S$. rolfsii populations was clearly presented by the authors like Harlton et al., (1995), Nalim et al., (1995), Okabe et al., (1998), Punja and Sun (2001), Sarma et al., (2002) and Shukla and Pandey (2007) but the presence of variation within the geographical regions is not well studied. This forms a crucial step in designing strategies to manage the disease as this helps in documentation of changes happen in the population (Sarma et al., 2002) and also to understand the population structure in designing efficient management strategies to reduce disease outbreak (Epsita Swain et al., 2018). Development of efficient breeding strategies to incorporate the resistance to these isolates in the cultivated types will help to overcome the problem and effective for a longer period of time. But isolates variability documentation in the cultivated regions of chickpea is very crucial for making proper management strategies. We are making concrete efforts to document the variability in chickpea growing areas of Kurnool district by collecting the samples. In the present study, efforts were made to document morphological variability among the Sclerotium rolfsii isolates of Kurnool district of Andhra Pradesh.

\section{Materials and Methods}

A roving survey was conducted to record occurrence and distribution of collar rot disease incidence in the fields of chickpea in Kurnool district of Andhra Pradesh during rabi 2019-2020.

\section{Isolation of pathogen}

The selected plant samples in the roving survey were used for the isolation of the pathogen. The pathogen was isolated using tissue segment method as suggested by Rangaswami and Mahadevan (1999). The infected collar region of plant was cut into small pieces of about $0.5 \mathrm{~cm}$ through sterilized scalpel blade and were surface sterilized with $1 \%$ sodium hypochlorite for $30 \mathrm{sec}$ followed by washing with sterile distilled water for three times. They were kept on blotting paper to avoid excess water and were later transferred onto petriplates containing PDA medium and incubated at $23 \pm 1^{\circ} \mathrm{C}$. These cultures were kept under observation from time to time to note the growth of fungus. Axenic cultures of the fungus was obtained by single hyphal tip method and maintained on PDA. The fungus was identified based on mycelial and sclerotial characters (Barnett and Hunter, 1972).

\section{Cultural and morphological variability}

Eighteen isolates of $S$. rolfsii (KCSR 1-18) collected from different Mandals of Kurnool District, Andhra Pradesh were studied for their cultural and morphological characters on PDA. The mycelial disc of $4 \mathrm{~mm}$ diameter of each isolate was placed in the centre of the plate and replicated twice. The inoculated 
plates were incubated at $23 \pm 1^{\circ} \mathrm{C}$ for 20 days. They were studied for eight morphological characters based on mycelial (mycelia growth, colony colour, mycelial dispersion and appearance) and sclerotial (sclerotial colour, weight and shape, number of sclerotia and their arrangement on surface of media) parameters recorded from $3^{\text {rd }}$ to $20^{\text {th }}$ day of incubation, respectively, for each isolate (Bansal et al., 1990) along with total growth and growth rate. Radial growth of each colony in two directions at right angles was measured. Visual observations on sclerotial formation were recorded.

\section{Assessment of aggressiveness of isolates by pot culture method}

The pathogen was further purified and multiplied on jowar grains to carry out aggression test. Jowar grains were boiled in fresh water for 30 minutes and drained excess water allowed to cool down by adding 5 per cent sucrose. $200 \mathrm{~g}$ of jowar seeds are transferred into $500 \mathrm{ml}$ flasks and autoclaved. The flasks were allowed to cool at room temperature and inoculated with $5 \mathrm{~mm}$ culture discs of 5 days old $S$. rolfsii grown on PDA. Four discs per flask were added and the flasks were incubated for one week at $28 \pm 1{ }^{\circ} \mathrm{C}$.

A pot culture experiment in the glass house was conducted to know the variation in aggressiveness of the eighteen isolates of $S$. rolfsii and to the pathogenic potential in terms of time taken for disease expression of each isolate of $S$. rolfsii and per cent of disease incidence on chickpea susceptible variety, L 550.

Soil inoculation method was adopted to test the aggressiveness among $S$. rolfsii isolates (Haware and Nene, 1980). The plastic pots of size $45 \times 30 \mathrm{~cm}$ each containing $3 \mathrm{kgs}$ of autoclaved soil were used for raising the host plants. The two week old mass cultured $S$. rolfsii isolates was mixed with the soil in pots @ $50 \mathrm{~g} \mathrm{Kg}^{-1}$ soil. The seeds of chickpea (var. L 550) were sown in the pathogen inoculated soil@10 seeds per pot. The observations were recorded up to 20 DAI by maintaining two replications in each treatment. Per cent disease incidence was calculated by using the following formula.

PDI $=\frac{\text { Number of diseased plants }}{\text { Total number of plants }} \times 100$

\section{Results and Discussion}

The present study with 18 isolates of Sclerotium rolfsii collected from the chickpea growing villages of Kurnool district of Andhra Pradesh indicated the existence of considerable variation in terms of morphological and cultural traits of the mycelia and sclerotia.

\section{Morphological variability in mycelial parameters}

The data pertaining to the mycelia growth and growth rate of different isolates is presented in the Table 1 and Plate 1. The isolates showed great variability for total growth from $40 \mathrm{~mm}$ (KSCR 16) to $72 \mathrm{~mm}$ (KCSR 1) after $72 \mathrm{hrs} / 3 \mathrm{DAI}$. The average total growth of the isolates was $56.22 \mathrm{~mm}$. Ten isolates showed more than average total growth while eight isolates recorded lower than the average value of total growth. Each isolate growth rate varied from $15 \mathrm{~mm} /$ day (KCSR 16) to 25 $\mathrm{mm}$ /day (KCSR 11) and the average growth rate was $19.22 \mathrm{~mm} /$ day. Nine isolates showed more than $19.22 \mathrm{~mm}$ /day growth while others showed less than $19.22 \mathrm{~mm} /$ day growth. This growth rate is used for the differentiating the isolates as slow, medium and fast growing types. The isolates with growth rate from 15 to $18 \mathrm{~mm} /$ day are grouped as moderate types (KCSR 5, KCSR6, KCSR7, KCSR12, KCSR13, KCSR15 and KCSR 16). The 
isolates with growth rate of 19 to $22 \mathrm{~mm} /$ day are classified as fast growing isolates (KCSR 1, KCSR 2, KCSR 3, KCSR 4, KCSR 8, KCSR 10, KCSR 14, KCSR 17 and KCSR 18) while, growth rate of 23 to $26 \mathrm{~mm} /$ day are characterized as very fast growing types (KCSR9 and KCSR11). The highest and lowest growth rates per day are observed in KCSR 11(25) and KCSR 16(15.2), respectively This data clearly indicated the existence of fast growing isolates in Kurnool district of Andhra Pradesh.

The mycelial colony characters (colony colour and appearance) of $S$. rolfsii isolates on PDA are presented in Table 2. The mycelial colour was varied from pure/extra white (KCSR 2, KCSR 6, and KCSR 7) to dull/ cottony white (KCSR 15 and KCSR 16) and white in other 13 isolates. The appearance of the isolates, KCSR 10, KCSR 11 and KCSR 14, was flower like while the isolates, KCSR 1, KCSR 5, KCSR 8, KCSR 15 and KCSR 16 , showed cottony growth on the media. The isolates, $\mathrm{KCSR} 6$ and $\mathrm{KCSR} 7$, appearance was dense mat like and the isolates, KCSR 4 and KCSR 9, showed wavy like pattern on the growth media. Among the isolates, KCSR 16 showed upright growth and KCSR 17 appearance was sparse on the media indicating these isolates different in its appearance and growth of the mycelia per day. Some isolates were similar in their morphological traits and growth pattern which is due to the genetic differences only as they were grown in controlled conditions on PDA (Okereke and Wokocha, 2007).

\section{Morphological variability in sclerotial parameters}

The sclerotial characteristics like time for their formation, colour, site of production, number and weight of 100 sclerotia varied in the studied isolates of $S$. rolfsii and the results are presented in the Table 3 and Plate 2.
The isolates took five to ten days for sclerotial production. The isolates KCSR 13 and KCSR 18 took 5 days for sclerotial production revealing the early entry into sclerotial formation. The colour of sclerotia showed great variation from dark brown (KSCR 1, KCSR 2, KCSR 5, KCSR 6, KCSR 10, KSCR 13 and KSCR 15), brown (KSCR 7, KSCR 9, KCSR 12 and KSCR 14), light brown (KCSR 3, KSCR 4, KSCR 8, KSCR 11 and KSCR 17) and golden brown in KCSR 18 to black in KSCR 16. The sclerotial production site in the isolates showed huge variation and the isolates, KCSR 1, KCSR 2, KCSR 4 and KCSR 5 produced clustered/ grouped sclerotial bodies; KCSR 3, KCSR 9, KCSR 10, KCSR 13, KCSR 14 and KCSR 17 produced single scattered sclerotial bodies all over the plate; KCSR 6, KCSR 7 and KCSR 8 produced sclerotial bodies to side walls of petriplate; KCSR 12 produced scleotial bodies around periphery; KCSR 11 and KCSR 18 produced sparse sclerotial bodies at periphery; KCSR 15 and KCSR 16 produced scleotial bodies on top of petriplate. Variations in sclerotial parameters have been reported by different scientists on various hosts and media (Sarma et al., 2002; Palaiah and Adiver, 2006 and Srividya et al., 2018).

The number of sclerotia ranged from 25 (KCSR 18) to 124 (KCSR 13) among isolates after 20 days of incubation. The weight of 100 sclerotia varied from 40mg (KCSR 1) to $320 \mathrm{mg}$ (KCSR 16). But the number of sclerotia is inversely proportional to the weight of 100 sclerotia as it was clearly seen in the isolates, KCSR 2, KCSR 3, KCSR 16 and KCSR 18 where the number is less but the weight is more while some of the isolates showed high sclerotia number with minimum weight as seen in KCSR 1. Some produced very less number of sclerotia with with minimal weight. The variation in sclerotial forming capacity could be a useful parameter in characterizing the isolates in the present 
study as the number of sclerotia showed great variability in the study.

The very fast growing types produced sclerotia in 8-9 days but the number of sclerotia was varied among the isolates. The isolate, KSCR 11, produced sclerotia in 8 days with the number of sclerotia were 75 at 20 DAI. This is in confirmation with the report of Komathi (2002) who reported that highly virulent strains exhibited very rapid growth and produced huge number of sclerotia in the culture. Morphological characterization of isolates based on variability in mycelia and sclerotial parameters in Sclerotium rolfsii has been reported by different scientists on different hosts (Punja and Grogan, 1983; Harlton et al., 1995; Punja and Damiani, 1996; Zarani and Christensin, 1997; Butler and Day, 1998; Okabe et al., 1998; Carpenter et al., 1999; Almeida et al., 2001; Sarma et al., 2002; Adandonon et al., 2005; Palaiah and Adiver, 2006; Okereke and Wokocha, 2007; Akram et al.,2007; Shukla and Pandey, 2007; Sachin et al., 2009; Rakholiya and Jadeja, 2011; Sharma et al., 2013; Thilaghavathi Rasu et al., 2013; Manjunath et al., 2014; Reddi et al., 2014; Jabbar et al.,2014; Manu et al.,2018; Poonam et al.,2018; Srividya et al., 2018).

Table.1 Total growth and growth rate of 18 isolates of S. rolfsii on PDA after 72 hrs of inoculation

\begin{tabular}{|l|l|c|c|}
\hline S. No. & Isolate & Growth $(\mathbf{m m})$ & Growth rate (mm/day) \\
\hline $\mathbf{1}$ & KCSR 1 & 60 & 19.5 \\
\hline $\mathbf{2}$ & KCSR 2 & $\mathbf{6 0}$ & 20.0 \\
\hline $\mathbf{3}$ & KCSR 3 & 60 & $\mathbf{2 0 . 2}$ \\
\hline $\mathbf{4}$ & KCSR 4 & 56 & 20.0 \\
\hline $\mathbf{5}$ & KCSR 5 & 42 & 18.0 \\
\hline $\mathbf{6}$ & KCSR 6 & 52 & 16.0 \\
\hline $\mathbf{7}$ & KCSR 7 & 54 & 16.0 \\
\hline $\mathbf{8}$ & KCSR 8 & 68 & 22.0 \\
\hline $\mathbf{9}$ & KCSR 9 & 64 & 23.0 \\
\hline $\mathbf{1 0}$ & KCSR 10 & $\mathbf{6 0}$ & 22.0 \\
\hline $\mathbf{1 1}$ & KCSR 11 & 50 & $\mathbf{2 5 . 0}$ \\
\hline $\mathbf{1 2}$ & KCSR 12 & 58 & 16.0 \\
\hline $\mathbf{1 3}$ & KCSR 13 & 52 & 19.0 \\
\hline $\mathbf{1 4}$ & KCSR 14 & 44 & 18.5 \\
\hline $\mathbf{1 5}$ & KCSR 15 & $\mathbf{4 0}$ & 16.0 \\
\hline $\mathbf{1 6}$ & KCSR 16 & 62 & $\mathbf{1 5 . 2}$ \\
\hline $\mathbf{1 7}$ & KCSR 17 & 58 & 21.0 \\
\hline $\mathbf{1 8}$ & KCSR 18 & $\mathbf{5 6 . 2}$ & 19.0 \\
\hline $\mathbf{A v e r a g e}$ & & & $\mathbf{1 9 . 2}$ \\
\hline & & & \\
\hline
\end{tabular}


Table.2 Colony characteristics of 18 isolates of $S$. rolfsii

\begin{tabular}{|c|c|c|c|c|}
\hline S. No. & Isolate & Growth & Colony colour & Mycelial Appearance and dispersion \\
\hline 1 & KCSR 1 & Fast & White & Slight cottony, sparse at centre ,dense at margins. \\
\hline 2 & KCSR 2 & Fast & Extra white & Thin strands at centre, dense at margin upright growth. \\
\hline 3 & KCSR 3 & Fast & White & Aggregate at centre thick strands towards margin. \\
\hline 4 & KCSR 4 & Fast & White & Sparse, thread like thin strands. \\
\hline 5 & KCSR 5 & Moderate & White & $\begin{array}{l}\text { Aggregate at centre, light cottony thin strands, branches like pattern } \\
\text { towards margin. }\end{array}$ \\
\hline 6 & KCSR 6 & Moderate & Extra white & Mat like appearance sparse at centre thick strand towards margin. \\
\hline 7 & KCSR 7 & Moderate & Extra white & Mat like appearance sparse at centre thin strand towards margin. \\
\hline 8 & KCSR 8 & Fast & White & $\begin{array}{l}\text { Slight cottony upward growth at centre, thin strands, suppressed, wavy } \\
\text { like pattern towards margin. }\end{array}$ \\
\hline 9 & KCSR 9 & Very Fast & White & Thin strands, suppressed, wavy like pattern. \\
\hline 10 & KCSR 10 & Fast & White & Flower like appearance thin strands. \\
\hline 11 & KCSR 11 & Very Fast & White & Flower like appearance dense around centre and sparse toward margin. \\
\hline 12 & KCSR 12 & Moderate & White & Thick strand branches like pattern. \\
\hline 13 & KCSR 13 & Moderate & White & Thin hair like sparse growth, dense around centre. \\
\hline 14 & KCSR 14 & Fast & White & Flower like appearance, sparse growth dense towards margin. \\
\hline 15 & KCSR 15 & Moderate & Cottony white & Fluffy, dense at margins, aggregate at centre\& upright growth. \\
\hline 16 & KCSR 16 & Moderate & Cottony white & Fluffy, dense at margins, aggregate at centre \& upright growth. \\
\hline 17 & KCSR 17 & Fast & White & Thin strands, suppressed, wavy like pattern. \\
\hline 18 & KCSR 18 & Fast & White & Sparse at centre thin strands dense towards outer margin. \\
\hline
\end{tabular}

Table.3 Sclerotial characteristics of 18 isolates of S. rolfsii

\begin{tabular}{|c|c|c|c|c|c|c|c|}
\hline S. No. & Isolate & $\begin{array}{l}\text { Days to } \\
\text { formation }\end{array}$ & Colour & Shape & Arrangement & $\begin{array}{l}\text { Number } \\
\text { at } 20 \text { DAI }\end{array}$ & $\begin{array}{c}100 \\
\text { sclerotia } \\
\text { weight }(\mathrm{g})\end{array}$ \\
\hline 1 & KCSR 1 & 10 & Dark brown & Round & $\begin{array}{l}\text { Clustered at centre and } \\
\text { periphery }\end{array}$ & 96 & 40 \\
\hline 2 & KCSR 2 & 9 & Dark Brown & Round & Clustered to sides of petriplate & 48 & 180 \\
\hline 3 & KCSR 3 & 9 & Light Brown & Irregular & Scattered & 32 & 140 \\
\hline 4 & KCSR 4 & 8 & Light Brown & Round & Clustered at peripheral & 52 & 220 \\
\hline 5 & KCSR 5 & 7 & Dark Brown & Oval & Peripheral single & 94 & 140 \\
\hline 6 & KCSR 6 & 10 & Dark Brown & Spherical & Peripheral clustered & 40 & 180 \\
\hline 7 & KCSR 7 & 10 & Brown & Oval & To sides of petriplate & 65 & 130 \\
\hline 8 & KCSR 8 & 8 & Light Brown & Spherical & To sides of petriplate & 99.5 & 190 \\
\hline 9 & KCSR 9 & 9 & Brown & Irregular & Scattered all over plate & 97 & 90 \\
\hline 10 & KCSR 10 & 8 & Dark Brown & Round & Scattred all over plate & 84 & 150 \\
\hline 11 & KCSR 11 & 8 & Light Brown & Round & $\begin{array}{l}\text { Peripheral and top of } \\
\text { petriplate }\end{array}$ & 75 & 100 \\
\hline 12 & KCSR 12 & 8 & Brown & Oval & around peripheral & 80 & 120 \\
\hline 13 & KCSR 13 & 5 & Dark Brown & Round & Scattered all over plate & 124 & 130 \\
\hline 14 & KCSR 14 & 7 & Brown & Spherical & Scattered on periphery & 50 & 110 \\
\hline 15 & KCSR 15 & 9 & Dark brown & Round & $\begin{array}{l}\text { Scatterd on top of the } \\
\text { petriplate }\end{array}$ & 90 & 170 \\
\hline 16 & KCSR 16 & 8 & Black & Spherical & $\begin{array}{l}\text { Scatterd on top of the } \\
\text { petriplate }\end{array}$ & 72 & 320 \\
\hline 17 & KCSR 17 & 9 & Light Brown & Round & Scattered & 51 & 70 \\
\hline 18 & KCSR 18 & 5 & Golden brown & Round & Peripheral & 25 & 100 \\
\hline
\end{tabular}


Table.4 Aggressiveness of different isolates of S. rolfsii at $20^{\text {th }}$ DAI on Chickpea variety L 550

\begin{tabular}{|l|l|c|c|}
\hline S. No. & Isolate & $\begin{array}{c}\text { Time taken for disease } \\
\text { expression (DAI) }\end{array}$ & $\begin{array}{c}\text { Per cent of disease incidence } \\
\text { (PDI) }\end{array}$ \\
\hline $\mathbf{1}$ & KCSR 1 & 11 & 75.00 \\
\hline $\mathbf{2}$ & KCSR 2 & 15 & 44.44 \\
\hline $\mathbf{3}$ & KCSR 3 & 10 & 84.50 \\
\hline $\mathbf{4}$ & KCSR 4 & 12 & 90.75 \\
\hline $\mathbf{5}$ & KCSR 5 & $\mathbf{1 8}$ & 77.56 \\
\hline & KCSR 6 & 17 & $\mathbf{1 4 . 2 8}$ \\
\hline $\mathbf{7}$ & KCSR 7 & 12 & 25.00 \\
\hline $\mathbf{8}$ & KCSR 8 & 12 & 81.55 \\
\hline $\mathbf{9}$ & KCSR 9 & 16 & 79.50 \\
\hline $\mathbf{1 0}$ & KCSR 10 & 11 & 37.78 \\
\hline $\mathbf{1 1}$ & KCSR 1 & 9 & 71.60 \\
\hline $\mathbf{1 2}$ & KCSR 1 & 10 & 90.00 \\
\hline $\mathbf{1 3}$ & KCSR 13 & 9 & 87.00 \\
\hline $\mathbf{1 4}$ & KCSR 14 & 13 & 91.00 \\
\hline $\mathbf{1 5}$ & KCSR 15 & $\mathbf{8}$ & 69.78 \\
\hline $\mathbf{1 6}$ & KCSR 16 & 14 & $\mathbf{9 3 . 3 3}$ \\
\hline $\mathbf{1 7}$ & KCSR 17 & 10 & 52.22 \\
\hline $\mathbf{1 8}$ & KCSR 18 & - & 81.00 \\
\hline $\mathbf{1 9}$ & Control & & 0.00 \\
\hline
\end{tabular}

Mean of two replications

Plate.1 Mycelial growth of S. rolfsii isolates on PDA after 7 DAI

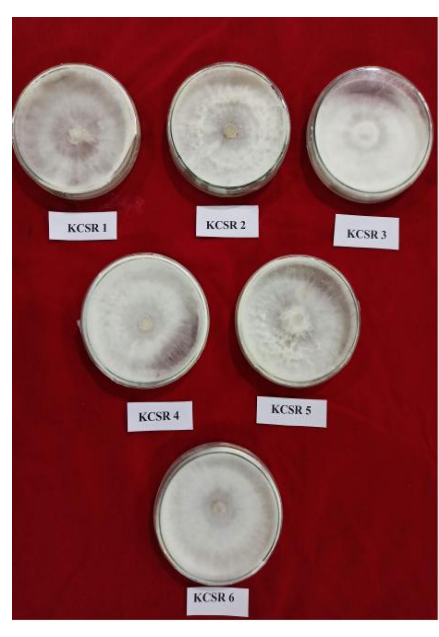

(A)

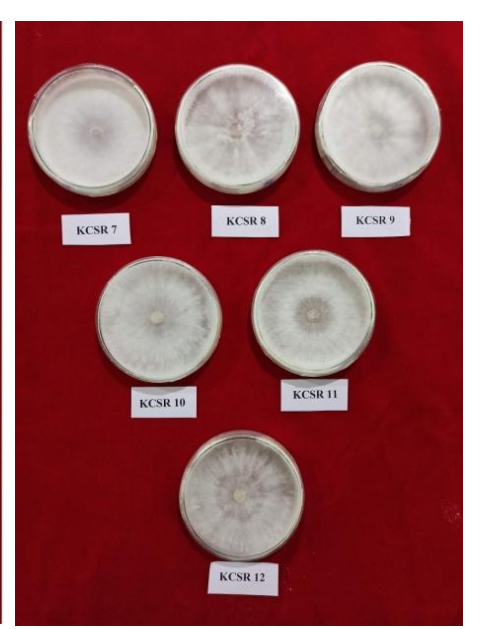

(B)

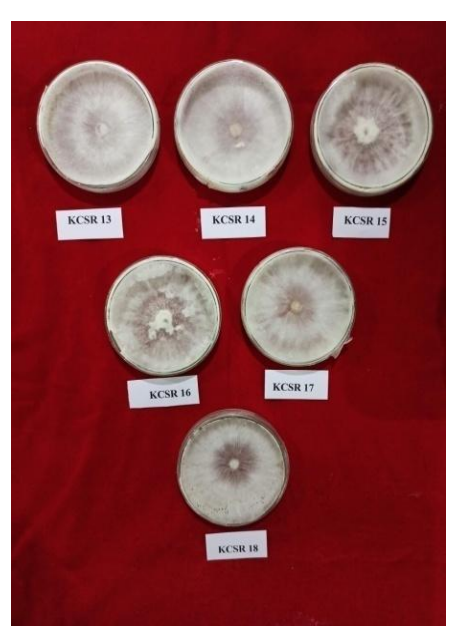

(C)

\section{KCSR 1- KCSR 6}

KCSR 7 - KCSR 12
KCSR 13 -KCSR 18 
Plate.2 Sclerotia production of $S$. rolfsii isolates on PDA after 20 DAI

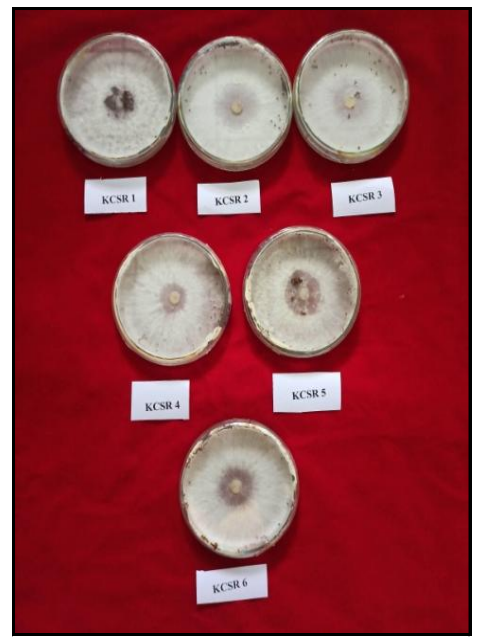

(A)

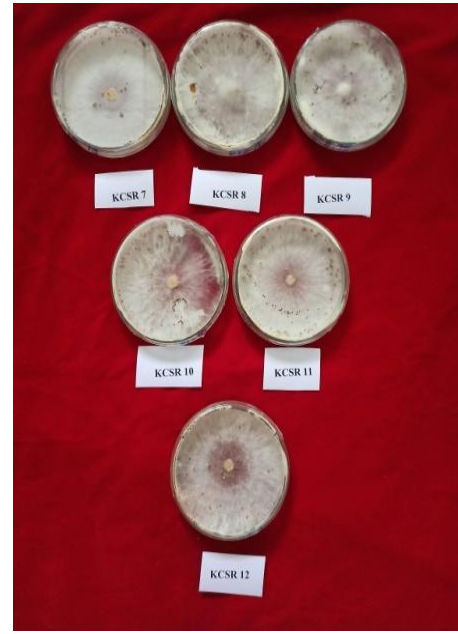

(B)

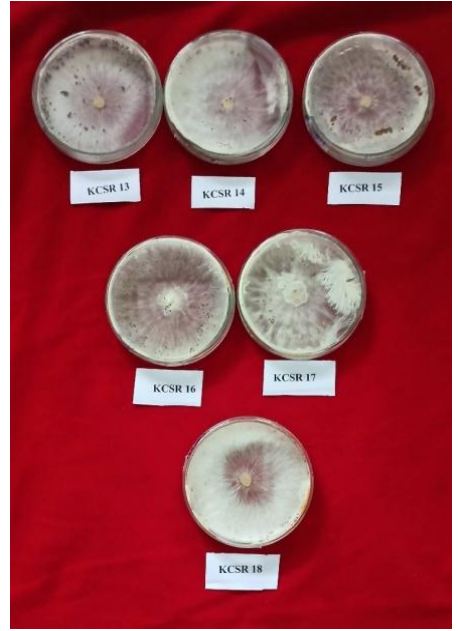

(C)
KCSR 1- KCSR 6

KCSR 7 - KCSR 12

KCSR 13 -KCSR 18

\section{Assessment of aggressiveness of isolates by pot culture method}

The pot culture experiment was conducted to test the aggressiveness i.e., quantitative variation of pathogenicity on susceptible host, of each isolate on chickpea susceptible variety, L 550 through Percentage of Disease Incidence (PDI). The pathogen was inoculated in jowar grains for mass multiplication and the multiplied isolates were mixed with the soil in pots. The seedling mortality was recorded at 20 days after pathogen inoculation and calculated the per cent of disease incidence (PDI).

The aggressiveness of isolates was studied on chickpea variety L 550 along with a control and the results are presented in the Table 4. The PDI values ranged from 14.28 (KCSR 6) to 95.67 (KCSR 16) among the isolates indicating huge variability among the isolates in disease causing nature. The isolates, KCSR 14, (91\%) KCSR 4 (90.75\%) and KCSR 12 (90.00\%) also showed very high PDI values while, the isolates, KCSR 6 (14.28), KCSR 7
(25\%) and KSCR 10 (37.78\%) recorded lower values of PDI. The isolate KCSR 16 took eight days for the disease expression whereas the isolate KCSR 6 took 18 days indicating the less aggressiveness of the isolate in causing disease. Thus, the isolate, KCSR 16 is considered as the most aggressive isolate as it produced the symptoms in eight days with high PDI among the isolates followed by the isolates, KCSR 14, KCSR 4, KCSR 12 and KSCR 13. Similar reports of identification of aggressive isolates were reported in the studies of Santha Lakshmi et al., (2010), Muthukumar and Venkatesh, (2013), Sivakumar et al., (2016), Daniel Jebaraj et al., (2016), Dabbas and Shrawan Kumar (2016), Ranga Rani et al., (2017), Durga Prasad et al., (2018) and Anitha Kumari and Abhjeet Ghatak (2018).

The presence of huge variations among the isolates of $S$. rolfsii can be attributed to the differences in physiological and metabolic rates exist in the isolates arising from different geographical and ecological systems and also their biochemical variability to adapt 
to the local conditions. The existence of variability among $S$. rolfsii populations was reported by earlier workers (Harlton et al., 1995 and Okabe et al., 1998). The studies on variability within the population of a geographical region are crucial as these studies documented the changes occurring in the population over time periods and facilitate us to design a effective strategy to manage the disease.

Thus, the study reported great variability in the pathogen in a limited area. The variation in cultural, mycelial and sclerotial morphological traits and pathogenicity amongst the isolates revealed that $S$. rolfsii can be characterized by a combination of these traits. The differences in morpho and cultural traits can be taken as potential parameters for differentiating isolates. Further, morphological characterization is a basic key for identification and for devising effective strategies to manage the disease including resistance breeding programmes.

\section{Acknowledgements}

The first author is highly thankful to Bayer Crop Sciences, India and Acharya NG Ranga Agricultural University for providing fellowship during M. Sc (Ag.) programme.

\section{References}

Aycock, R. 1966. Stem rots and other diseases caused by Sclerotium rolfsii or the status of Rolf's fungus after 70 years. North Carolina Agricultural Experiment Station Technical Bulletin.174: 202.

Almeida, A.M.R., Abdelnoor, R.V., Calvo, E.S., Tessnman, D and Yorinori, J.T. 2001. Genotypic diversity among Brazilian isolates of Sclerotium rolfsii. Journal of Phytopathology. 149 (9): 493-502.

Adandonon, A., Aveling, T.A.S., Merwe, N.A.V and Sanders, G. 2005. Genetic variation among Sclerotium isolates from
Benin and South Africa, determined using mycelial compatibility and ITS rDNA sequence data. Australian Plant Pathology. 34: 19-25.

Akram, A., Iqbal, M.S.H., Ahmed, N., Iqbal, U and Ghafoor, A. 2008. Morphological variability and mycelial compatibility among the isolates of Sclerotinia sclerotiorum associated with stem rot of chickpea. Pakistan Journal of Botany. 40 (6): 2663-2668.

Anitha Kumari and Abhijeet Ghatak.2018. Variability in Chickpea Rot-causing Soilborne Necrotrophs, Sclerotium rolfsii and Macrophomina phaseolina. Journal of AgriSearch. 5(4):247-253.

Barnett, H.L and Hunter, B.B. 1972. Illustrated Genera of Imperfect Fungi. Burgess Publishing Company, Minnesota, USA.

Butler, M. J and Day, A.W. 1998. Fungal melanins: A review. Canadian Journal of Microbiology. 44: 1115-1136.

Bansal, R. K. and Sobti, A. K. 1990. An economic remedy for the control of two spec Aspergillus on groundnut. Indian Phytopathology.43: 451-452.

Carpenter, M. A., Frampton, C and Stewart, A. 1999. Genetic variation in New Zealand population of pathogen Sclerotinia sclerotiorum. New Zealand Journal of Crop and Horticultural Sciences. 27: 13-21.

Dabbas. M. and Shrawan Kumar. 2016. Effect of pathogenic, cultural variability and chemical management of Sclerotium rolfsii. International Journal of Plant Protection. 9(2): 395- 400.

Daniel, M. J., Arutkani, K.E., Aiyanathan and Nakkeeran, S. 2017. Virulence and genetic diversity of Sclerotium rolfsii Sacc. infecting groundnut using nuclear (RAPD \& ISSR) markers. Journal of Environmental Biology. 38: 147-159.

Ghosh, R., Mamta Sharma, Rameshwar Telangre, and Suresh Pande. 2013. Occurrence and Distribution of Chickpea Diseases in Central and Southern Parts of India. American Journal of Plant Sciences. (4): 940-944.

Haware, M. P and Nene, Y.L. 1980. Screening 
chickpea for resistance to wilt. Plant Disease. 64: 379-380.

Harlton, C.E., Levesque, C.A and Punja, Z.K. 1995. Genetic diversity in Sclerotium rolfsii and related species. Phytopathology. 85: 1269-1281.

Jabbar S., Nagaraja, A. Mallikarjun and Manu, T. G. 2014. Variability among the Sclerotium Rolfsii Sacc. isolates from Southern Karnataka. International Journal of Agricultural Sciences. (2): 229-236

Kotasthane, S. R., Agrawal, P.S., Joshi, L.K., Laxman and Singh. 1976. Studies on wilt complex in bengalgram. Jawahar Lal Nehru Krishi Vishwa Vidyalaya Research Journal. 10: 257-258.

Komathi, K. 2002. Studies on biological management of root rot of groundnut (Arachis hypogaea L.) caused by Sclerotium rolfsii. M.Sc. (Ag.) Thesis, Agricultural College and Research Institute, Tamil Nadu Agricultural University, Madurai.

Lakshmi, M. S., Sujatha, K., Naresh, N. and Rao, S.C.2012. Variability in Sclerotium rolfsii associated with collar rotof sunflower.Indian Phytopathology. 65 (2): 161-165.

Maurya, S. D., Singh, H., Singh, J and Srivastava. 2008. Management of collar rot of Chickpea (Cicer arietinum) by Trichoderma harzianum and plant growth promoting Rhizobacteria. Journal of Plant Protection Research. 48 (3): 347-354.

Muthukumar, A. and Venkatesh, A. 2013. Effect of light and aeration on the growth of Sclerotium rolfsii in vitro. African Journal of Biotechnology. 12(49): 68436846.

Manjunatha, N., Devi, T.P., Prabhakaran, N., Navali, G. V. and Pati, S.S. 2014. Morphological and molecular diversity of Sclerotinia sclerotiorum (Lib.) De Bary isolates of India. An International Quarterly Journal of Lifesciences. 9(4): 1763-1767.

Manu, T. G., Nagaraja, A and Manjunatha, S.V. 2018. Morphological and cultural variability among the Sclerotium rolfsii isolates. Journal of Pharmacognosy and Phytochemistry. 7 (1): 904-907.

Nalim, F. A., Starr, J.L., Woodard, K.E., Segner, S and Keller, N.P. 1995. Mycelia compatibility groups in Texas peanut field populations of Sclerotium rolfsii. Phytopathology. 85: 1507-1512.

Nagamani, P., Biswas, M.K and Bhagat, S. 2015. Status of root rot diseases in chickpea growing Rayalaseema region of Andhra Pradesh. An International Journal Society for Scientific Development. 10 (4): 320322.

Okabe, I., Morikawa, C., Matsumoto, N and Yokoyama, K. 1998. Variation in Sclerotium rolfsii isolates in Japan. Mycoscience. 39(4): 399-407.

Okereke, V.C and Wokocha, R.C. 2007. In vitro growth of four isolates of Sclerotium rolfsii Sacc. in the humid tropics. African Journal of Biotechnology. 6 (16): 1879-1881.

Punja, Z. K and Grogan, R.G. 1983. Hyphal interactions and antagonism among field isolates and single-basidiospore strains of Athelia (Sclerotium) rolfsii. Phytopathology. 73: 1279-1284.

Punja, Z. K and Damiani, A. 1996. Comparative growth, morphology and physiology of three Sclerotium species. Mycologia. 88: 694-706.

Punja, Z. K and Sun, L.J. 2001. Genetic diversity among mycelia compatibility groups of Sclerotium rolfsii (teleomorph Athelia rolfsii) and Sclerotium delphinii. Mycological Research. 105: 537-546.

Palaiah, P and Adiver, S.S. 2006. Morphological and cultural variability in Sclerotium rolfsii Sacc. Karnataka Journal of Agriculture Science. 19 (1): 146-148.

Padole Sachin, Om Gupta and Madhuri Mishra 2009. Variability among isolates of Sclerotium rolfsii Sacc. causing collar rot of chickpea. Journal of Food Legumes. 22(2):127-130.

Poonam, P., Shete, Pankaj, B., Deore and Kasal, Y.G., 2018. Studies on sclerotial characteristics of Sclerotium rolfsii isolates of groundnut on different media. Plant Archives 18(1): 852-856. 
Rangaswami, G and Mahadevan, A. 1999. Diseases of Crop Plants in India. Prentice Hall of India Pvt. Ltd., New Delhi. 6079.

Rakholiya, K.B and Jadeja, K.B. 2011. Morphological diversity of Sclerotium rolfsii caused and pod rot of groundnut. Journal of Mycology and Plant Pathology. 41 (4): 500-504.

Raju, G., Sharma, M., Telangre, T and Pande, S. 2013. Occurrence and distribution of chickpea diseases in central and southern parts of India. American Journal of Plant Sciences. 4: 940-944.

Reddi, M. K., Santhoshi, M.V.M., Krishna, T.G and Reddy, K.R. 2014. Cultural and morphological variability Sclerotium rolfsii isolates infecting groundnut and its reaction to some fungicides. International Journal of Current Microbiology and Applied Sciences. 3 (10): 553-561.

Rani, A. R. 2017. Stem rot of groundnut incited by Sclerotium rolfsii Sacc. and it's management. International Journal of Agricultural Science and Research. 7(3): 327- 338.

Subramanian, K. S. 1964. Studies on sclerotial root disease of groundnut (Arachis hypogaea L.) by Sclerotium rolfsii Sacc. Madras Agricultural Journal. 51: 367-378.

Sarma, B. K., Singh, U.P and Singh, K.P. 2002. Variability in Indian isolates of Sclerotium rolfsii. Mycologia. 94 (6): 1051-1058.

Shukla, R and Pandey, A.K. 2007. Diversity in isolates of Sclerotium rolfsii isolated from Central India. Journal of Mycology and Plant Pathology. 37 (3): 514-518.

Sharma, P., Meena, P.D., Sandeep, K and Chauhan, J.S. 2013. Genetic diversity and morphological variability of Sclerotinia sclerotiorum isolates of oilseed Brassica in
India. African Journal of Microbiology Research. 7 (18):1827-1833.

Sivakumar, T., Sanjeevkumar, $\mathrm{K}$ and Balabaskar, P. 2016. Variability in Sclerotium rolfsii Sacc. causing Stem rot of groundnut. Bulletin of Environment, Pharmacology and Life Sciences. 22771808 (2) 92- 99.

Srividya, P.V., Lal Ahamed. M., Ramana, J.V and Khayum Ahmmed, S. 2018. Cultural and morphological characterization of Sclerotium rolfsii Sacc. causing collar rot in chickpea. International Journal of Current Microbiology and Applied Sciences. 7(6): 3912-3922.

Swain, E., Archana. A., Gadekar, Mane, S.S. and Meher, J. 2018. Determination of genetic diversity among Sclerotium rolfsii isolates causing collar rot of chickpea using simple sequence repeat (SSR) markers. International Journal of Current Microbiology and Applied Sciences 7 (6): 2319-7706

Singh, R. P., Singh, A.K., Upadhyay, S.P and Singh, R.K. 2020. Integrated insect-pest and disease management for productivity enhancement in pulse crops. Journal of Entomology and Zoology Studies. 8(2): $1433-1440$

Thilaghavathi, R., Sevugapperumal, N., Thiruvengadam, $\mathrm{R}$ and Ramasamy, $\mathrm{S}$. 2013. Morphological and genomic variability among Sclerotium rolfsii populations. The Bioscan. 8 (4): 14251430.

Zarani, F and Christensin, C. 1997. Sclerotial biogenesis in basidiomycetes-Sclerotium rolfsii. Mycologia. 89: 592-602.

\section{How to cite this article:}

Saileela, M., M. Lal Ahamed, J. V. Ramana and Khayum Ahamed, S. 2020. Morphological Characterization of Kurnool Strains of Chickpea Collar Rot Casual Agent Sclerotium rolfsii Sacc.. Int.J.Curr.Microbiol.App.Sci. 9(09): 211-221. doi: https://doi.org/10.20546/ijcmas.2020.909.027 